\title{
Математичні моделі і методи організації інноваційних систем комп'ютерного моніторингу мереж електропостачання залізниць
}

Приведені результати аналізу моніторингу в енергетищі, показано, щзо новітні досягнення в сфері мережевих і інтелектуальних технологій принципово по новому поставили питання організації глобального комп'ютерного моніторингу в залізничній енергетииі, запропоновано комплекс понять комп'ютерного моніторингу, щзо обтрунтовано відображають особливості функиіонування залізничних мереж, $i$ наведені математичні моделі організації інноваційних систем всережимного комп'ютерного моніторингу залізничних енергосистем.

Ключові слова: комп'ютерний моніторинг, прочеси, оптимізація, електропостачання, інформаційний простір, математичні моделі, система.

\begin{abstract}
Постановка проблеми
Сучасні тенденції наукових досліджень розвитку як світової енергетики, так і енергетики залізничного транспорту, пов'язані 3 «інтелектуалізацією» швидкоплинних технологічних процесів генерації електроенергіï, ऑiі передачі, розподілу, керування комерційним споживанням в умовах ринку та сервісного обслуговування $[1,2]$. Пошук нових шляхів розв'язання проблеми інтелектуалізації режимів функціонування електричних мереж залізничного транспорту стимулював проведення ряда наукових досліджень в сфері створення нових принципів організації комп'ютерних середовищ, математичних моделей, методів і комп'ютерно-орієнтованих алгоритмів оптимального функціонування тягових систем. В цьому плані, загальновизнаним у світі $€$ напрям наукових досліджень інтелектуалізації в енергетиці, який отримав назву SMART Grid технології, що означає по суті організовану самоконтролюючу, аналізуючу і звітуючу технології на основі принципів самовідновлення і саморегуляції 3 керуванням в реальному часі на основі єдиного розподіленого інтегрованого обчислювального середовища, завдяки чому відкрилась можливість наповнювати електроенергетику залізниць новими «знаннями» [2, 7]. Поява SMART Grid - технологій відкрила можливість реалізувати, 3 єдиних загальносистемних позицій, інноваційне перетворення тягових електричних мереж залізниць шляхом організації глибокої взаємної інтеграції електромережевої топології та інформаційної архітектури інфраструктури комп'ютерного середовища управління, що забезпечить оптимізацію
\end{abstract}

(C) O.I. Стасюк, Л.Л. Гончарова, 2016 електроспоживання, покращити рівень безпеки руху і створити сучасні комп'ютерні енергозберігаючі технології на залізницях. Головним, при цьому, $\epsilon$ організація всережимного комп'ютерного моніторингу як основи повномасштабного інформаційного забезпеченням для проведення, в реальному часі, оптимізації режимів функціонування системи електропостачання, аналізу i прогнозу аварійних ситуацій, зміни топології електричної мережі і пї параметрів, а також розширення комерційних ринкових можливостей та сервісних послуг, включаючи формування комп'ютерної культури електроспоживання і стимулювання процедур економічного розвитку.

Аналіз останніх досліджень і публікацій

показав, що еволюція розвитку тягових електричних мереж залізниць і автоматизованих комп'ютерних систем керування режимами електропостачання тісно пов'язана 3 новітніми досягненнями в сфері комп'ютерних, інформаційних, мережевих i комунікаційних технологій [3 - 5]. Особливість мереж постачання електроенергії на тягу залізниць характеризується значним рівнем динаміки режимів електроспоживання, великою кількістю силових електричних компонентів функціонуючих в широкому спектрі частот, значною величиною «рухомого» навантаження, а також несиметричним навантаженням, обумовленим організацією однофазної тягової системи змінного струму. Рішення глобального комплексу задач, пов'язаних 3 організацією енергозбереження, безпеки руху і оптимального керування електричним господарством залізниць, неможливо без широкого впровадження сучасних та перспективних комп'ютерних, інформаційних інтелектуальних технологій i методів інтелектуалізації керування швидкоплинними технологічними процесами 
електроспоживання, захисту, електропостачання та формування сучасних комерційних відносин в сфері ринку електроенергії. Розв'язання проблеми комп'ютеризації і створення сучасних інтелектуальних технологій електропостачання та покращення якості споживання електроенергії і безпеки перевезень $\epsilon$ основою інноваційного перетворення тягових електричних мереж залізниць, що дає можливість різко підвищити ефективність функціонування режимів тягової електричної мережі i, що дуже важливо, накопичувати нові «знання» в процесі роботи. Останні дослідження в сфері комп'ютеризації швидкоплинних процесів в енергетиці показали, що створення інтелектуальних тягових мереж з можливістю зміни в реальному часі навантажень шляхом регулювання сукупності параметрів топології мережі, оптимізації планування режимів, реєстрації виникненню порушень i аварійних ситуацій 3 подальшим їх аналізом i прогнозом розвитку, неможливе без створення єдиного інформаційного простору синхронно зареєстрованих параметрів в різних сегментах електричної мережі на основі проведення безперервного ковзкого комп'ютерного моніторингу на всіх рівнях генерації, перетворення, передачі, розподілу i споживання електричної енергії [7].

\section{Відокремлення нерозв'язаних раніше частин загальної проблеми}

Завдяки бурному розвитку інтегральних
технологій виготовлення надвеликих інтегральних схем, мікропроцесорних засобів, і на їх базі, створення комп'ютерних, інформаційних та мережевих технологій, стало можливим принципово по новому поставити питання організації всережимного комп'ютерного моніторингу швидкоплинних процесів електроенергетичних об'єктів і мереж залізниць [1, 3, 6]. Класичне поняття моніторингу включає в себе непереривний процес спостереження та реєстрації параметрів стану об'єкту. В той же час, завдяки сучасним комп'ютерним технологіям i перспективними методам комп'ютеризації та інтелектуалізації процедур управління i оптимізації швидкоплинних режимів функціонування систем електропостачання залізниць, настала нагальна потреба введення нових понять комп'ютерного моніторингу в залізничній енергетиці. Завдяки впровадженню в сферу енергетики новітніх досягнень в сфері мережевих і інтелектуальних технологій, сукупність нових понять комп'ютерного динамічного моніторингу мають обгрунтовано відображати особливості функціонування залізничних мереж електропостачання на тягу, характерні характеристики архітектур мікропроцесорного втілення у вигляді розподіленого обчислювального середовища, принципову єдність спільних i узгоджених задач оперативного i стратегічного керування електроспоживанням і забезпечити суттєве розширення функціональних можливостей всережимного моніторингу силових електричних об'єктів та динаміку режимів електросистем в реальному часі. Комп'ютерний моніторинг в залізничній енергетиці, в зв'язку 3 високим рівнем динаміки режимів тягових електричних мереж, представляється автоматичним, в тому випадку, якщо немає відповідних застережень. Принциповою відмінністю комп'ютерного моніторингу в залізничній енергетиці має бути те, що процедури моніторингу розглядаються не тільки як спостереження поточного стану електричного об'єкту, а також оцінка технічного та технологічного режиму функціонування залізничних енергетичних систем, включаючи їх ретроспективний аналіз, прогноз надійності в різноманітних умовах зовнішнього середовища, а також, в деяких випадках, формування в реальному часі керуючих впливів та представлення інформації, яка відображається у вигляді графіків, даних, показань, суджень тощо.

\section{Мета роботи}

Наукове обгрунтування системи понять і термінів проблеми комп'ютерного моніторингу в залізничній енергетиці i розробка математичних моделей та методів організації інноваційних систем всережимного моніторингу силового електричного обладнання та мереж електропостачання залізниць.

\section{Основний матеріал дослідження}

Концептуальною базою створення інноваційних систем комп'ютерного моніторингу є необхідність в сумісному і узгодженому рішенні глобальних задач підвищеної складності і розмірності таких як: аналіз результатів всережимного комп'ютерного моніторингу, включаючи ретроспективу, технічна діагностика i оцінка стану електричних об'єктів i систем, прогноз надійності їх функціонування i оперативне керування електроспоживанням. Незважаючи на відносну автономність цих задач, вони находяться в системній єдності і взаємозалежності друг $з$ другом. Враховуючи найрізноманітніші зв'язки між подіями, що з'являються в електроенергетичних системах, а також велику швидкість протікання основних технологічних процесів електропостачання, для формування систем сучасного моніторингу використаємо перспективні напрямки, пов'язані 3 інтеграцією інтелектуальних комп'ютерно орієнтованих методів моделювання вищевказаних глобальних задач. Новітні досягнення в сфері комп'ютерних, інтелектуальних і телекомунікаційних технологій, а також поява сучасних методів автоматичного i оперативного керування електропостачанням, на сьогоднішній день, дозволили забезпечити, в реальному часі, управління режимами 
функціонування електроенергетичних об'єктів та систем, а також кількісне i якісне спостереження швидкозмінних параметрів режимів, притаманних особливостям електричних мереж і об'єктів залізниць. В зв'язку з цим, проблему моніторингу в залізничній енергетиці необхідно вирішувати, починаючи, в першу чергу, зі створення комплексу понять і термінів, які в сукупності відображали би можливості сучасних і перспективних комп'ютерних, інформаційних і мережевих технологій керування електропостачанням, i закінчувати розробкою та впровадженням перспективних інноваційних систем комп'ютерного моніторингу в залізничній енергетиці. Система понять комп'ютерного моніторингу стимулює пошук нових шляхів, принципів організації і методів синтезу нового класу інноваційних комп'ютерних систем проведення всережимного моніторингу залізничних електричних мереж, що відкриває величезні можливості наповнювати енергетику, в першу чергу, новими знаннями, як основою суттєвого підвищення ефективності i надійності ऑii функціонування, оптимізації режимів електроспоживання в реальному часі і покращити безпеку руху. Отримані в процесі комп'ютерного моніторингу нові знання дозволять зробити суттєвий ривок в сфері розробки нових методів конструювання інтелектуального силового електричного обладнання тягових підстанцій і мереж електропостачання, методики їх експлуатації, створити перспективні енергозберігаючі технологій на залізничному транспорті і поставити ряд проблем удосконалення комп'ютерних мереж i систем керування електропостачанням.

В основі поняття «комп'ютерний моніторинг в залізничній електроенергетиці» розуміється спеціально організоване розподілене комп'ютерне середовище, що забезпечує в реальному часі, синхронне векторне вимірювання первинних даних параметрів режимів силового електричного обладнання та мереж залізниць, включаючи навколишнє середовище i організацію єдиного інформаційного i часового середовища 3 загальносистемних позицій, з метою проведення:

на рівні комп'ютеризації режимів електропостачання - безперервного контролю за швидкоплинними процесами, об'єктами i явищами включаючи формування, в реальному часі, керуючих впливів, реалізації,

на рівні інформатизації процедур оперативного управління - аналізу, включаючи ретроспективу, оцінку технічного стану i прогнозу надійності функціонування, для визначення сукупності кількісних і якісних характеристик,

на рівні інтелектуалізації мереж електропостачання - організація повномасштабного інформаційного забезпечення для проведення оперативного i стратегічного керування 3 метою оптимізації режимів створення сучасних енергозберігаючих технологій електропостачання, формування комплексу сервісних послуг в умовах ринку електроенергії, створення комп'ютерного сервісу ринкових взаємовідносин і стимулювання економічного розвитку.

Суттєві відмінності поняття «комп’ютерний моніторинг в залізничній електроенергетиці» від класичного заключаються, в першу чергу, в великій різноманітності, а також своєрідності фізичних явищ і задач в залізничній електроенергетиці, великій швидкодії і глобальності технологічних процесів електропостачання, що визиває необхідність комп'ютерного забезпечення безперервності процесу електроспоживання, надзвичайні великі наслідки в результаті порушень і системних аварій, пов'язаних 3 безпекою руху. Все це в комплексі виставляє відповідні вимоги до комп'ютерного моніторингу залізничної енергетики. Дослідження в сфері проведення моніторингу складних енергетичних об'єктів показав, що реєстрація всієї первинної інформації не $є$ доцільною. Для повного аналізу достатньо проводити реєстрацію первинної інформація перед появою аномального режиму системи електропостачання, а також отримання даних аномального i iнформації після закінчення аномального режимів, спільно з допоміжними даними, зареєстрованими синхронно за часом та пов'язаними 3 захистом мережі. Цей факт стимулював введення поняття «ковзкий комп'ютерний моніторинг». Під цим терміном розуміється організація постійної реєстрації, в пам'яті комп'ютерного середовища, n первинних даних всіх параметрів режиму мережі електропостачання за проміжок часу $\tau$. Далі дані $(n+1)^{\text {го }}$ виміру кожного параметру записуються в першу комірку пам'яті комп'ютерного середовища, $(\mathrm{n}+2)^{\text {го }}$ - в другу комірку i т. п. Таким чином зорганізується ковзка реєстрація первинної інформації кожного iз комплексу параметрів режиму електромережі 3 використанням тільки n комірок пам'яті для контролюємого параметру. Відповідно, при появі аномального або аварійного режиму, в пам'яті комп'ютерного середовища залишається $\mathrm{n}$ зареєстрованих значень кожного параметру доаварійного процесу, а також проводиться реєстрація всіх параметри аварійного і післяаварійного режимів. Отримана аварійна інформація формується 3 загальносистемних позицій в єдиному інформаційному середовищі для подальшого використання.

Більш глибокий аналіз процесів та явищ, які протікають в залізничних мережах на рівні дистанції електропостачання, що характеризується високим ступенем взаємоінтеграції електромережевої топології залізниці і комп'ютерної архітектури інфраструктури керування електроспоживанням, можливо проводити шляхом регулярного визначення сукупності вторинних параметрів. Процес керування електропостачанням на 
рівні дистанції залізниці потребує не тільки сучасних засобів інформатизації, а і можливості часткової автоматизації зміни іiі топології для забезпечення оптимального електропостачання. Тому під терміном «комп'ютерний моніторинг вторинних параметрів режимів енергосистеми» розуміється визначення, на основі сучасних комп'ютерно - орієнтованих методів, комплексу показників для керування в реальному часі потоками активної електроенергії і компенсації реактивної потужності i, на їх базі, оптимізації електроспоживання, формування сучасних енергозберігаючих технологій, забезпечення комерційного сервізу між сегментами дистанції електропостачання і обленерго.

Всесистемний, глобальний моніторинг електричної тягової мережі залізниці для іiі повної комплексної оцінки вцілому, прогнозу технічного стану i комерційних складових управління, забезпечення високого рівня експлуатаційних і ринкових сервізних послуг, керування ресурсами і вимогам сучасних бізнес - процесів, реалізується шляхом проведення інтелектуального комп'ютерного моніторингу. Термін «інтелектуальний комп'ютерний моніторинг» відображає комп'ютерне визначення сукупності показників для об'єднання інформаційних технологій i інтеграції та інтелектуалізації процедур керування ресурсами технологічного i організаційного управління мережею електропостачання залізниці, формування і накопичення нових знань в залізничній енергетиці, управління, в реальному часі, енергозбереженням, незбалансованими потоками потужності, якістю та запасом стійкості системи, проведення дистанційного комп'ютерного контролю всіх компонентів електромережі, організацію безпеки і конфіденційності IT- системи i комерційної інформації.

Завдяки введенню сукупності нових понять комп’ютерного моніторингу в залізничній енергетиці відкривається можливість організації первинних даних у вигляді єдиного багаторівневого інформаційного i часового простору і обробки первинної інформації 3 загальносистемних позицій в комп'ютерному середовищі за допомогою сучасних методів ситуаційного моделювання. Використовувати, в реальному часі, набір внутрішніх i зовнішніх динамічних даних для суттєвого зниження ризику неадекватного вибору цілей і стратегій при організації інноваційних перетворень залізничної енергетики та підвищити ступінь комп'ютерних ринкових послуг, включаючи рівень довіри елекропостачальників i споживачів електроенергії.

Схемна реалізація інноваційної системи комп'ютерного моніторингу мереж електропостачання залізниць і силового електричного обладнання тягових підстанцій наведена на рис. 1. Комп'ютерний моніторинг в залізничній енергетиці представлений у вигляді трьох рівнів:

рівень тягових підстанцій, на якому використовується, в основному, ковзкий комп'ютерний моніторинг параметрів режимів електромережі;

рівень дистанції електропостачання, де застосовується комп'ютерний моніторинг вторинних параметрів режимів тягової енергосистеми;

третій - рівень залізниці, на якому проводиться інтелектуальний комп'ютерний моніторинг.

На першому рівні тягових підстанцій системи електропостачання, первинна інформація реєструється за допомогою мікропроцесорних регістраторів інформації (MPI) на виходах датчиків, які находяться в різних сегментах мережі електропостачання, силового електричного обладнання i систем релейного i мікропроцесорного захисту. Отримані первинні дані, у вигляді аналогових, дискретних і цифрових сигналів, $є$ основою формування багаторівневого інформаційного середовища, організованого 3 загальносистемних позицій. Первинні дані реєструються за допомогою проведення ковзкого комп'ютерного моніторингу i можуть бути

$$
\begin{aligned}
& i_{k}=F_{k}^{i}\left(i_{k}^{d}, i_{k}^{a}, i_{k}^{p}, U_{k}, t_{k}, D_{j}, \theta_{e}, f, \tau, U_{k}^{i}, Z_{k}^{i}, V_{k}^{i}\right) \\
& u_{k}=F_{k}^{u}\left(u_{k}^{d}, u_{k}^{a}, i_{k}^{p}, i_{k}, t_{k}, D_{j}, \theta_{\epsilon}, f, \tau, U_{k}^{u}, Z_{k}^{u}, V_{k}^{u}\right) \\
& \lambda_{k}=F_{k}^{\lambda}\left(\lambda_{k}^{d}, \lambda_{k}^{a}, \lambda_{k}^{p}, i_{k}, u_{k}, t_{k}, \theta_{\theta}, f, \tau, U_{k}^{\lambda}, Z_{k}^{\lambda}, V_{k}^{\lambda}\right)(1) \\
& D_{j}=F_{j}^{D}\left(D_{j}^{d}, D_{j}^{a}, D_{j}^{p}, i_{k}, u_{k}, t_{j}, \theta_{e}, f, \tau, U_{j}^{D}, V_{j}^{d}\right) \\
& \mathrm{k}=1,2 . \mathrm{n}, \mathrm{j}=1,2 . \mathrm{m},
\end{aligned}
$$

де $\lambda_{k}, D_{j}-$ аналогові i дискретні сигнали; $i_{k}^{d}, u_{k}^{d}, \lambda_{k}^{d}, D_{j}^{d}$ - сигнали доаварійного режиму; $i_{k}^{a}, u_{k}^{a}, \lambda_{k}^{a}, D_{j}^{a}$ - сигнали аварійного режиму; $i_{k}^{p}, u_{k}^{p}, \lambda_{k}^{p} D_{j}^{p}-$ сигнали післяаварійного режиму; $f$ - частота; $t$ - проміжок часу доаварійного режиму; $U_{k}$ - параметри, що визначають синхронність, а часом реєстрацію; $V_{k}$ - параметри, що характеризують ряд особливостей формування первинної інформації; $\theta$ параметри даних навколишнього середовища.

$$
\text { Значення } \theta_{\ominus} \text { i } t_{\gamma} \text { можуть бути записані як }
$$

$$
\begin{aligned}
& \theta_{e}=F_{e}^{\theta}\left(i_{k}, u_{k}, Z_{e}^{\theta}, t_{e}, U_{e}^{\theta}, V_{e}^{\theta}\right) \\
& t_{\gamma}=F_{\gamma}^{t}\left(i_{k}, u_{k}, \theta_{e}^{t}, f, Z_{\gamma}^{t}, U_{\gamma}^{t}, V_{\gamma}^{t}\right) \\
& \gamma=1,2, . . \mathrm{z}, \quad e=1,2, . . \mathrm{r} .
\end{aligned}
$$




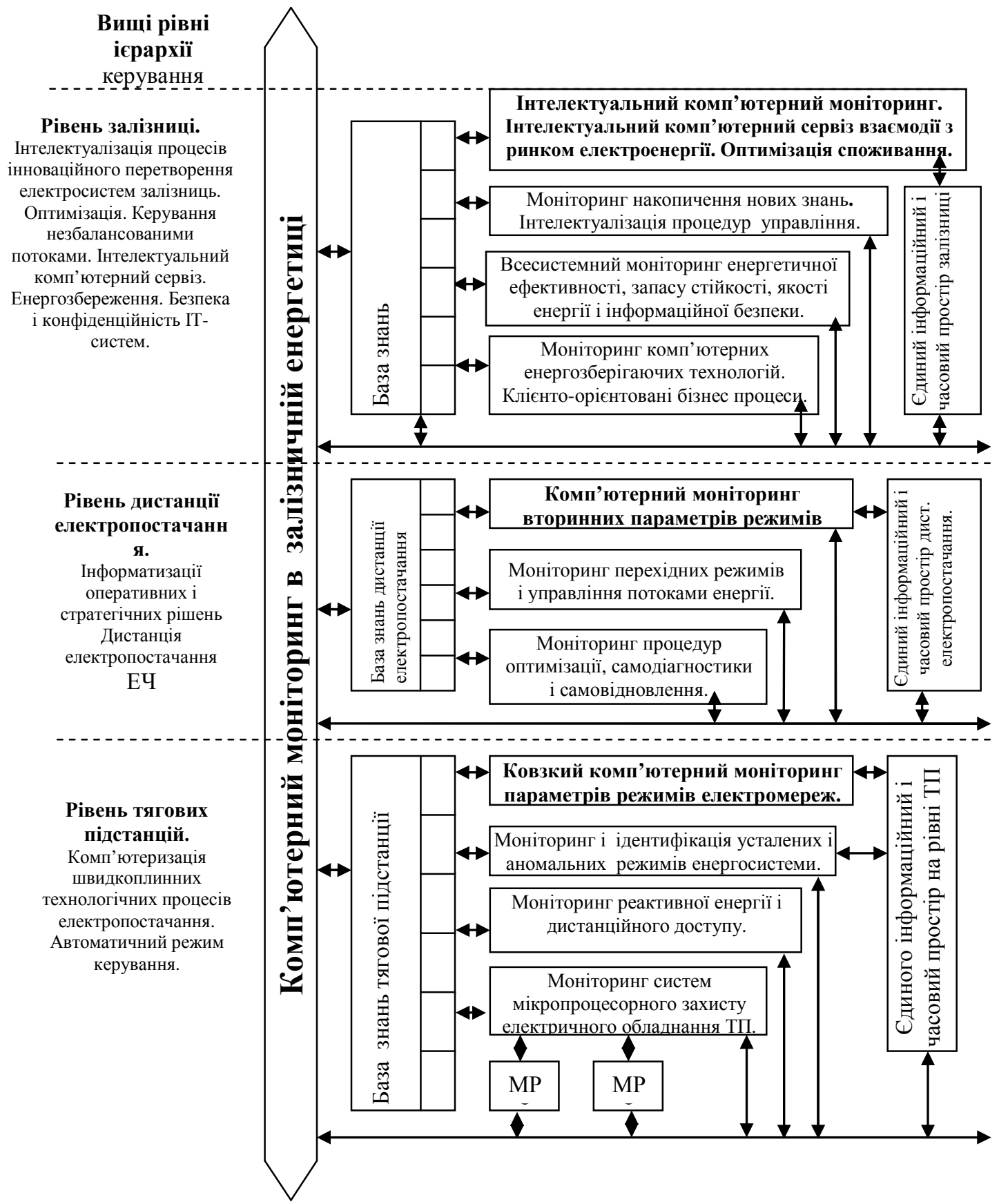

Рис. 1. Інноваційна система всережимного комп’ютерного моніторингу мереж і об'єктів електропостачання залізниць

Представимо первинні дані $t_{k}, u_{k}, \lambda_{k}, D_{j}, t_{y}, \theta_{e}$ у вигляді множин $G^{i}, G^{n}, G^{\lambda}, G^{D}, G^{t}, G^{\theta}$ у вигляді
$\left\{i_{k}\right\} \in G^{i} \neq \emptyset$,
$\left\{u_{k}\right\} \in G^{u} \neq 0$,
$\left\{\lambda_{k}\right\} \in G^{\lambda} \neq \varnothing$
$\left\{D_{j}\right\} \in G^{D} \neq \emptyset$,
$\left\{t_{\gamma}\right\} \in G^{t} \neq \emptyset$,
$\left\{\theta_{e}\right\} \in G^{\theta} \neq \varnothing$

Процедура формування єдиного інформаційного i часового простору може бути представлена у вигляді множини $\mathrm{G}$ як

$$
\begin{aligned}
& G=G^{i} \cup G^{u} \cup G^{\lambda} \cup G^{D} \cup G^{t} \cup G^{\theta} \neq \varnothing \\
& G=G^{i} \cup G^{u} \cup G^{\lambda} \cup G^{D} \cup G^{t} \cup G^{\theta}=\varnothing
\end{aligned}
$$


Процес інформатизації оперативних і стратегічних рішень на рівні дистанції електропостачання електромережі залізниці, реалізується за допомогою проведення комп'ютерного моніторингу вторинних параметрів режимів. Завдяки обчисленню комплексу параметрів, на основі первинної інформації представленої виразами (1)-(4), визначаються кількісні і якісні показники перехідних режимів, формуються керуючи впливи для управління потоками енергії та компенсації реактивної енергії, а також на рівні дистанції електропостачання реалізується оптимізації електроспоживання, процедури самовідновлення і самодіагностики, тощо. Комп'ютерний моніторинг сукупності кількісних і якісних вторинних параметрів 5 режиму швидкоплинних технологічних процесів електропостачання на тягу може бути записана у вигляді

$S=\Phi(i, u, \lambda, D, t, \theta, Z, U, V, \tau)$

Основним завданням, в процесі комп'ютерного моніторингу на рівні дистанції електропостачання, $\epsilon$ оптимізація режимів функціонування системи електропостачання таким чином, що із безкінечного числа оперативних і стратегічних керуючих впливів $Q^{i}=Q^{i}\left(Q_{1}^{i}, Q_{2}^{i}, \ldots Q_{n}^{i}\right)$ знаходиться такий $Q_{o p t}^{i}$, що задовольняє системі обмежень в процесі формування такого набору вторинних параметрів $S^{i}=S^{i}\left(S_{1}^{i}, S_{2}^{i}, \ldots S_{n}^{i}\right)$, щоб виконувався критерій оптимальності виду [6, 7]

$$
\begin{aligned}
& W_{\text {max }}=\max _{Q^{i}, s^{i}}\left\{W\left(Q^{i}, S^{i}\right)\right\} \\
& Q^{i}=Q^{i}\left(Q_{1}^{i}, Q_{2}^{i}, \ldots Q_{n}^{i}\right) \\
& S^{i}=S^{i}\left(S_{1}^{i}, S_{2}^{i}, \ldots S_{m}^{i}\right) .
\end{aligned}
$$

Визначення, в результаті комп'ютерного моніторингу, вторинних параметрів функціонування електромережі відкриває можливість миттєво реагувати на різноманітні нештатні ситуації i ефективно забезпечувати високі техніко-економічні показники електропостачання.

Для інтеграції процедур інтелектуалізації швидкоплинних технологічних процесів і сукупності інформаційних технологій керування ресурсами технологічного i організаційного управління електропостачанням залізниць, проводиться інтелектуальний комп'ютерний моніторинг. В результаті проведення інтелектуального комп'ютерного моніторингу реалізується, в реальному часі, оптимізація незбалансованих потоків потужності, якості і запасу стійкості енергосистеми, технологій енергозбереження i, що саме головне, формуються i накопичуються нові знання в процесі функціонування системи електропостачання. Отримані нові знання, в залізничній енергетиці, представляються у вигляді виявлених закономірностей, зв'язків, принципів, законів в предметній області. Тому останнім часом дослідниками ведеться широкий пошук математичних моделей і методів здобування і структурування знань придатних для програмної обробки в комп'ютерних мережах. Для цього потрібні моделі класифікації понять та обумовлений формат представлення знань. Дані, структуровані таким чином в деякій сфері предметної області, разом з властивостями конкретних об’єктів часто називають базою знань. Повноцінні бази знань утримують в собі не тільки фактичну інформацію, а і сукупність правил логічного виводу, що відкриває можливість формувати, в реальному часі, автоматичні висновки як по наявним, так і новим фактам, завдяки чому проводиться семантична обробка інформації.

Концептуальна модель, предметною областю якої є залізнична енергетика, может бути представлена у вигляді сукупності множин $\langle X, C, R, G\rangle$ в якій:

$X=\left\{x_{1}, x_{2}, \ldots x_{n}\right\}$ - множина об'єктів, кожний із яких має своє ім'я для організації процедури рішення задач керування, причому кожний об'єкт $x_{i}$ iз множини $X$ характеризується деякою сукупністю властивостей, тобто $x_{\mathrm{i}}=\left(c_{j}, c_{k}, \ldots c_{z}\right) ; C=\left\{c_{1}, c_{2}, \ldots c_{m}\right\}$ - множина імен властивостей об'єктів, що формуються із множини $X$;

$R=\left(r_{l}, r_{2}, \ldots r_{n}\right)-$ множина імен логічних відносин, що допускаються з об' єктами множини $X$;

$G=\left(g_{1}, g_{2}, \ldots g_{k}\right)$ - множина імен процедур і операцій які дозволено виконувати з об'єктами $X$ шляхом можливої зміни кількісних значень їх властивостей, а також відносин між ними. При такому підході, стан $\Psi\left(\mathrm{t}_{\mathrm{i}}\right)$ предметної сфери якою є залізнична енергетика, визначається сукупністю всіх властивостей і відносин кожного об' єкту $x_{i}$ із множини $X$. В фіксований момент часу $t_{i}$ стан системи електропостачання може бути представлений наступним виразом:

$\Psi\left(\mathrm{t}_{\mathrm{i}}\right)=\left\{\mathrm{X}\left(\mathrm{t}_{\mathrm{i}}\right), \mathrm{C}\left(\mathrm{t}_{\mathrm{i}}\right), \mathrm{R}\left(\mathrm{t}_{\mathrm{i}}\right)\right\}$.

В той же час, зміна стану $\Psi\left(\mathrm{t}_{\mathrm{i}}\right)$ реалізується під впливом процедур i операцій, представлених множиною $G$. Процедура отримання нових знань, в процесі функціонування системи електропостачання, представляється у вигляді сукупності послідовних

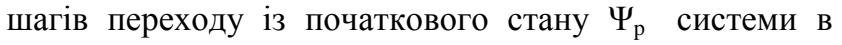
новий стан, який будемо називати цільовим або кінцевим станом $\Psi_{\mathrm{k}}$. Процес розв'язання поставленої задачі зводиться до визначення послідовності процедур, послідовне застосування яких до 
початкового стану системи $\Psi_{\mathrm{p}}$ переводить $\dddot{11}$ в кінцевий стан $\Psi_{\mathrm{k}}$, що може бути записано наступним виразом:

$\Psi_{\mathrm{k}}=\beta_{i}\left(\beta_{n}\left(\beta_{m}\left(\ldots \ldots \beta_{k}\left(\Psi_{\mathrm{p}}\right)\right)\right)\right)$.

Послідовність $\left(\beta_{i, \ldots} \beta_{n, . .} \beta_{m, .} \beta_{k}\right)$ представляє собою, в загальному вигляді, сукупність алгоритмів рішення задачі визначення нових знань. Пошук таких алгоритмів $\left(\beta_{i, \ldots} \beta_{n, . .} \beta_{m, .} \beta_{k}\right)$ покладається на експертну систему.

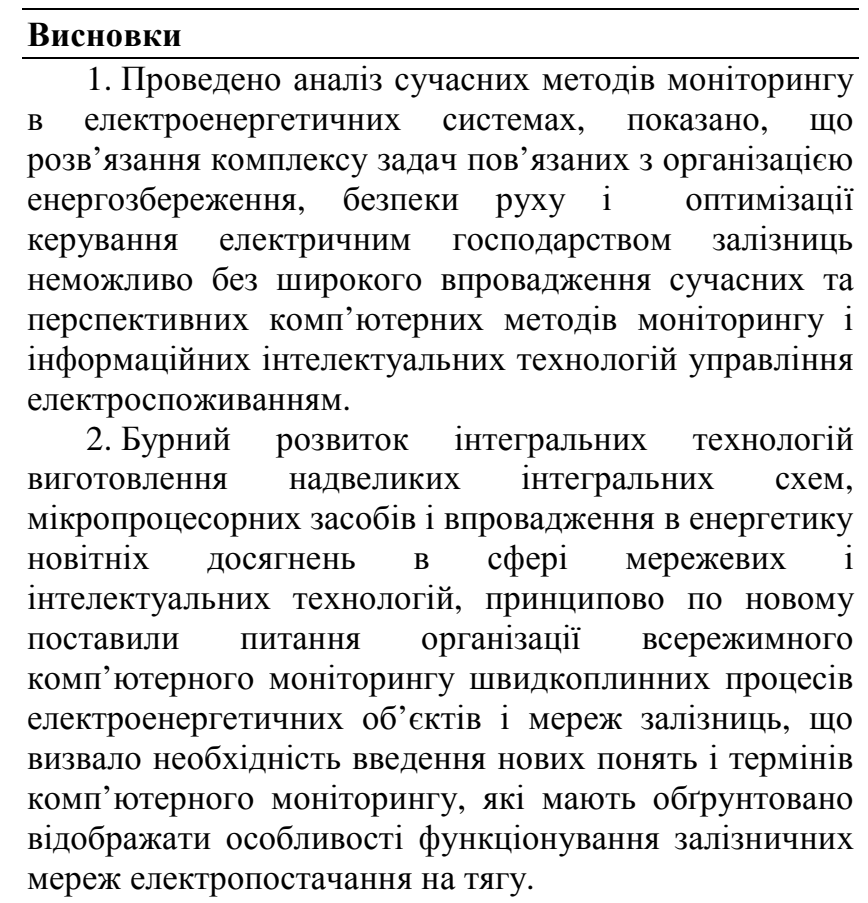

3. Для вирішення проблеми створення i впровадження перспективних інноваційних систем комп'ютерного моніторингу запропоновано комплекс понять і термінів таких як комп'ютерний моніторинг в залізничній електроенергетиці, ковзкий комп'ютерний моніторинг, комп'ютерний моніторинг вторинних параметрів режимів енергосистеми, інтелектуальний комп'ютерний моніторинг, що відкрило можливість організації первинних даних у вигляді єдиного багаторівневого інформаційного і часового простору для ефективної обробки первинної інформації 3 загальносистемних позицій.

4. На основі розроблених сучасних понять комп'ютерного моніторингу, для інтеграції процедур інтелектуалізації процесів електропостачання, запропоновано математичні моделі реалізації i, на їх базі, інноваційна система всережимного комп'ютерного моніторингу мереж i об'єктів електропостачання залізничного транспорту.
1. Стогній Б.С.

\section{Література} електроенергетиці. Про поняття моніторингу // Стогній Б.С., Сопель М.Ф.; Технічна електродинаміка 2013, №1 - С. 62-69.

2. Стасюк О.І. Методи організації інтелектуальних електричних мереж залізниць на основі концепції SMART Grid // Гончарова Л.Л., Максимчук В.Ф. Інформаційно-керуючі системи на залізничному транспорті, науково-технічний журнал, Харків 2014, № 2 -С. $29-37$.

3. Стасюк O.I. Підвищення надійності моніторингу допустимості завантажень контрольованих перетинів енергосистем // Стасюк O.I., Буткевич О.Ф., Левконюк А.В. Технічна електродинаміка, Київ - 2014, №2 - С.56-67.

4. Стасюк O.I. Методи комп'ютерної інтелектуалізації режимів функціонування тягових мереж залізниць// Стасюк O.I., Гончарова Л.Л., Максимчук В.Ф., Голуб Г.М. Інформаційнокеруючі системи на залізничному транспорті, науково-технічний журнал, Харків - 2013, № 5 C. $29-36$.

5. Стасюк О.I. Методи синтезу розподілених комп'ютерно-інтегрованих мереж і технологій інтелектуалізації, моніторингу та оптимізації режимів електропостачання i енергозбереження залізниць // Стасюк О.І., Гончарова Л.Л., Максимчук В.Ф. Інформаційно-керуючі системи на залізничному транспорті, науково-технічний журнал, Харків - 2015, № 1, С.23 -34.

6. Стасюк О.I. Методи організації мікропроцесорних архітектур захисту фідерів контактної мережі // Стасюк O.I., Гончарова Л.Л., Голуб Г.М. Інформаційно-керуючі системи на залізничному транспорті, науково-технічний журнал, № 4, 2015 - C.33-42.

7. Стасюк O.I. Математичні моделі і методи організації інтелектуальних мереж постачання електроенергії на тягу залізничному транспорту // Стасюк O.I., Гончарова Л.Л. Інформаційнокеруючі системи на залізничному транспорті, науково-технічний журнал, № 3, 2015 -С.25-31.

Стасюк А.И., Гончарова Л.Л. Математические модели и методы организации инновационных систем компьютерного мониторинга сетей електроснабжения железных дорог. Приведены результаты анализу мониторинга в энергетике, показано, что новейшие достижения в сфере сетевых и интеллектуальных технологий принципиально поновому поставили вопрос организации глобального компьютерного мониторинга в железнодорожной энергетике, предложен комплекс понятий компьютерного мониторинга, которые обоснованно 
отражают особенности функционирования железнодорожных сетей, и приведены математические модели организации инновационных систем всережимного компьютерного мониторинга железнодорожных энергосистем.

Ключевые слова: компьютерный мониторинг, процессы, оптимизация, электроснабжение, информационное пространство, математические модели, система.

Stasiuk A.I., Goncharova L.L. Mathematical models and methods of innovative computer monitoring systems of railways electric networks. The results of the monitoring analysis show that modern tendencies of scientific researches in the field of rail transport energy development are connected with the "intellectualization" of fast technological processes of commercial power supply for traction under market conditions. The latest achievements in the field of networking and smart technologies which raised the question of global computer monitoring organization in railway power engineering in a fundamentally new way have been considered. This fact is also confirmed by the rapid development of integrated technologies of manufacturing large scale integrated circuits and microprocessor devices for computerization of fast technological processes of electric power facilities and railway networks. The solution of the problem of creation and implementation of promising innovative computer monitoring systems has necessitated the introduction of new monitoring concepts and terms for that reasonably reflect the peculiarities of functioning of power supply railway networks for traction. A set of concepts and terms, such as computer monitoring in the railway power engineering, computer monitoring of power system mode secondary parameters, intelligent computer monitoring has been proposed. In order to integrate intellectualization procedures of power consumption processes, mathematical models and based on them innovative system of fullyvariable computer monitoring of networks and power supply facilities of railway transport have been proposed.

Key words: computer monitoring, processes, optimization, power supply, information space, mathematical models, system.

Рецензент д.т.н., професор Тимченко Л.I. (ДЕТУТ)
Stasiuk O. I. Doctor of engineering, professor, head of department "Automation and Computer-Integrated Technologies of Transport" State Economic and Technological University of Transport, laureate of the State Prize of Ukraine, Kyiv, Ukraine.

Goncharova L. L., Ph.D., Assistant professor, department "Automation and Computer-Integrated Technologies of Transport" State Economic and Technological University of Transport, Kyiv, Ukraine.

Стасюк Олександр Іонович, доктор технічних наук, професор, лауреат Державної премії в галузі науки $i$ техніки, завідувач кафедри «Автоматизачія та комп'ютерно - інтегровані технології транспорту», Державний економіко-технологічний університет транспорту, Київ, Украӥна.

Гончарова Лідія Леонідівна, кандидат технічних наук, дочент кафедри «Автоматизачія та комп'ютерноінтегровані технології транспорту», Державний економіко-технологічний університет транспорту, Киів, Україна. 